\title{
Viscoelastic Fluid Flow in the Half-Spherical Gap in the Rotation of Outer Sphere in Dual Spheres
}

\author{
Hiroshi Yamaguchi, and Naoya OHara \\ Department of Mechanical Engineering, \\ Doshisha University, 1-3 TataraMiyakotani, Kyo-tanabeshi \\ Kyoto 610-0321, Japan
}

\begin{abstract}
Flow of viscoelastic fluid contained between a stationary inner half-sphere and a rotating outer sphere was studied experimentally. Measurements of the stationary torque and thrust of the inner half-sphere were made. The situation of uniquely appearing flow for viscoelastic fluids were obtained by flow visualization. The measurement results of torque and thrust showed that Reynolds number and a gap ratio influenced the torque characteristics substantially, while the thrust is much effected by the elastics effect. Resultant experiment data was arranged by empirical formula for given geometric configuration, using the Deborah number together with the generalized Reynolds number.
\end{abstract}

Key Words: Spherical Couette flow / Deborah number / Elastic effect / Torque characteristics / Thrust characteristic

\section{二重球殼の外球殼回転時における粘弾性流体の半球間隙流れ}

\author{
山口 博司*, 大原 直也
}

(原稿受理 : 2002年3月27日)

\begin{abstract}
1. 緒言
流体工学における流体機械や回転機械が曲面状の間隙を 持つ場合がある.この場合, 重要となる流れの形態の一つに, 球クエット流れ（Spherical Taylor Couette flow）がある。これ は, 径の異なる二球間隙内の流れであり, 流体力学的基礎研 究分野から流体工学的応用分野に至るまで様々な研究がな されている1) 5).

また，プラスチック原料に代表されるような高分子（ポリ マー）は，粘弾性流体（Viscoelastic Fluid）であり，非ニュー トン粘性や法線応力効果等のレオロジ一特性を有する. 非 ニュートン粘性によりせん断粘度はひずみ速度に依存し，ま た, 弾性効果としての法線応力効果により張力が流線方向に 発生し, 張力に垂直な方向に圧力が生じる. よって, 粘弾性 流体はニュートン流体には見られない様々な流動特性を示 す.これまで粘弾性流体の球クエット流れについては，山口

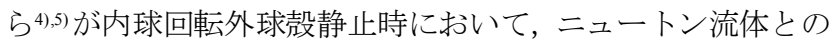
比較を行い, レオロジー特性によるトルク特性の変化を実験 的および解析的に報告している。 これら, 粘弾性流体の球ク エット流れは, 低レイノルズ数において内球回転, 外球款回 転を問わず赤道面対称であり, 上半球, 下半球の流れは対称 流れとなる. 一方, 内球を下半球のみにした場合, 赤道面で 流れの対称性が崩れる. この場合について, 山口らの゙が内半 球回転外球款静止時に, 内半球がトルクのみならずスラスト
\end{abstract}

同志社大学工学部機械系学科

T 610-0321 京都府京田辺市多々羅都谷 1-3
力を受けることや, 赤道付近にテイラー・ゲルトラ渦 (以下, T.G. 渦) と呼ばれる安定な渦列が発生し，レイノルズ数の増 加に伴い流れの構造を幾段階にも変化させることを報告し ている.この半球閒隙流れは, トルクコンバータに代表され る回転を伴う流体機器への応用, さらに半球回転粘度計等へ の応用が期待される.しかし，これらの流体工学的応用分野 における重要性にも関わらず, 粘弾性流体の半球間隙流れ は，未だ十分に研究がなされていないのが現状である.

そこで本研究では, 流体工学的応用を視野に半球間隙流れ をより詳しく調べるため, 外球殼回転内半球静止時における 粘弾性流体の半球閒隙流れの研究を行った. 供試流体として 希薄溶液でも粘弾性特性を良く示寸PAA(Polyacrylamide)高分 子の水溶液を使用した。実験では，比較のため内半球回転外 球殼静止時に層流から乱流まで変化するレイノルズ数領域 において, 内半球表面のトルクおよびスラスト力の測定を 行った。 また，流れの可視化を行い，主流および二次流れの 様子を観察した.

\section{2. 実 験}

\section{1 実験装置及び実験方法}

実験装置の概略を Fig.1に示す．内半球(1)は塩化ビニル製 で，外球殼(2)は可視化および写真撮影のためアクリル樹脂製 とした. 球クエット流れでは, 内球半径 $r_{1}$, また外球款内面 半径 $r_{2}$ とすると間隙比 $\beta=\left(r_{2}-r_{1}\right) / r_{1}$ が流れ場に対して非常に 大きい影響を及ぼすことが知られている，そこで， $r_{1}, r_{2}$ の選 
Table I Variation of gap ratio.

\begin{tabular}{|c|c|c|}
\hline $\begin{array}{c}\text { radius of inner hemisphere } \\
r_{1}[\mathrm{~mm}]\end{array}$ & $\begin{array}{c}\text { radius of outer sphere } \\
r_{2}[\mathrm{~mm}]\end{array}$ & $\begin{array}{c}\text { gap ratio } \\
\beta=\left(r_{2}-r_{1}\right) / r_{1}\end{array}$ \\
\hline 65 & 70 & 0.0769 \\
65 & 75 & 0.1538 \\
65 & 78 & 0.2000 \\
\hline
\end{tabular}

Process accuracy of the radii are smaller than $| \pm 0.1| \%$

定に際し, 内球回転外球殸静止時において遠心力不安定性が 発生し, T.G 渦の存在が確認され, 間隙比が比較的狭い場合 とされる $\beta \leq 0.33$ となるよう7), Table Iに示すような $r_{1}, r_{2}$ の組 み合わせによって 3 種類の間隙比 $\beta$ を用いることとした. ここ で内球および外球殼の表面は水力的平滑仕上げとした. 内球 軸は直径 $8 \mathrm{~mm}$ のジュラルミン製である. Fig.1に示すように, これらの球をカップリングを介し同心同軸に配置し，2球間 に供試流体を封入した. 本研究では内半球を静止, 外球殼は ターンテーブル(3)を介しモータ(5)により回転させた. 回転数 をインバータ(4)で制御し, 内半球表面にかかるスラスト力を 上部に設置されたロードセル6により測定した. また内半球 表面の摩擦トルクを内球軸に直結されたトルク検出器(7)に より測定した. ロードセル, トルク検出器から出力された信 号はアンプ(8), トルクメータ (9)により増幅し, A/D変換を行っ てコンピュータに入力した. なお, 本実験により求められる トルク, スラストカの計測值は, 最大值において計測誤差は それぞれ約 $\pm 2.0 \%, \pm 1.6 \%$ である.

実験に際しては, 流れのモードが回転加速度に影響される ことを考慮し ${ }^{8)}$, 外球の回転数は準静的に変化させ, 外球の 回転数を変える毎に充分な待ち時間（5分間）をおき，流れ のモードに変化がないことを確認した後に摩擦トルク，スラ

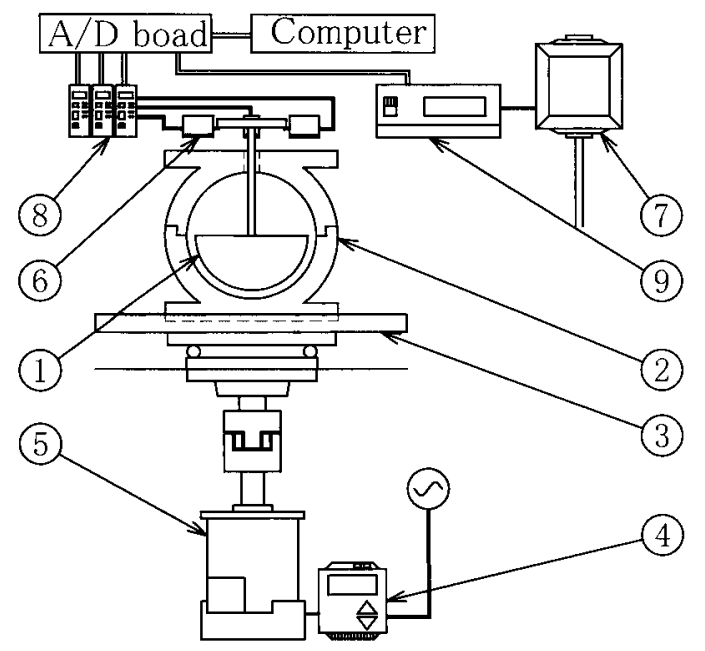
(1) inner hemisphere
(6) load cell
(2) outer sphere
(7) torque detecter
(3) turn table
(8) amplifier
(4) inverter controllor
(9) torque meter
(5) driving motor

Fig.1 Schematic diagram of the apparatus.
Table II-I Power-law model fitting parameters (range of shear rate : $1 \sim 240[1 / \mathrm{s}])$.

\begin{tabular}{|c|c|c|c|}
\hline \multirow{4}{*}{ PAA } & & $\begin{array}{c}m \\
{\left[\mathrm{mPa} \cdot \mathrm{s}^{n}\right]}\end{array}$ & \\
\hline \multirow{4}{*}{} & 500 & 70.05 & 0.6075 \\
\cline { 2 - 4 } & 1000 & 250.1 & 0.4550 \\
\cline { 2 - 4 } & 1500 & 517.9 & 0.3950 \\
\cline { 2 - 4 } & 2000 & 814.1 & 0.3625 \\
\hline
\end{tabular}

(for the shear viscocity $\eta=m \dot{\gamma}^{n-1}$ )

Table II-II Giesekus model fitting parameters (range of shear rate : $1 \sim 240[1 / \mathrm{s}])$.

\begin{tabular}{|c|c|c|c|c|c|}
\hline \multirow{4}{*}{ PAA } & & $\begin{array}{c}\eta_{\mathrm{p}} \\
{[\mathrm{Pa} \cdot \mathrm{s}]}\end{array}$ & $\begin{array}{c}\eta_{\mathrm{s}} \\
{[\mathrm{mPa} \cdot \mathrm{s}]}\end{array}$ & $\begin{array}{c}\text { relaxation time } \\
\lambda_{[}[s]\end{array}$ & $\begin{array}{c}\text { mobility factor } \\
\alpha\end{array}$ \\
\hline \multirow{4}{*}{} & 500 & 0.105 & 8.50 & 3.0 & 0.002 \\
\cline { 2 - 6 } & 1000 & 0.405 & 14.0 & 3.5 & 0.002 \\
\cline { 2 - 6 } & 1500 & 0.825 & 19.0 & 4.0 & 0.002 \\
\cline { 2 - 6 } & 2000 & 1.40 & 22.0 & 4.5 & 0.002 \\
\hline
\end{tabular}

スト力の測定を行った. 摩擦トルク, スラスト力の計測值は, $60 \mu \mathrm{sec}$ おに 16000 個のデータをコンピュータに取り込み, その平均值を代表データとした。一方，流れの可視化は供試 流体の中にアルミニウム粉末を分散させることにより流れ のモードを観測できるようにした，流れの可視化観測は装置 正面および子午線断面上より行い, 赤道面をはさんでそれぞ れ北半球, 南半球に現れる流れの様相について目視観測を行 なうとともに写真撮影を行なった。 ここで，供試流体に対す るアルミニウム粉末の濃度は $0.02 \% \mathrm{wt}$ 未満であり, 供試流体 の粘度および流れへの影響は見られなかった。

また，外球壳回転の摩擦による流体の温度変化は全ての実 験条件下において約 $0.5^{\circ} \mathrm{C}$ 以下と非常に小さく，物性に対す る温度補正の必要性は認められなかった。 なお, 実験環境温 度は実験装置全体を恒温室内に配置することで一定とし，こ の時の設定温度は $22.0^{\circ} \mathrm{C}$ した.

\section{2 供試流体}

本実験で用いた供試流体は，ニュートン流体としてグリセ リン水溶液, また, 粘弾性流体（非ニュートン流体）として, 希薄溶液においても顕著な粘弾性のレオロジー特性を示し9), 物性も比較的制御しやすいPolyacrylamide (三洋化成製 サンフ ロック AH-210P, 推定分子量約 $\left.1.6 \times 10^{7}\right)$ 水溶液 $(500,1000$, $1500,2000 \mathrm{ppm}$ 溶液）を用いた。 なお本実験では，これらの高 分子水溶液を PAA水溶液と称し, 溶液濃度別に区別した.

供試流体の作成にあたり PAA水溶液の溶解は擋找器を用い て行い, 撹找速度, 擋拌時間, および溶解温度 $\left(22.0^{\circ} \mathrm{C}\right)$ に 留意し, 各々の溶液の物性を全ての実験において同一かつ均 一となるように配慮した。 これらの供試流体のレオロジー特 性を Fig.2に示す.ここでFig.2-(1)はせん断粘度 $\eta[\mathrm{Pa} ・ \mathbf{s}]$, Fig.2(2)は第一法線応力差 $N_{1}[\mathrm{~Pa}]$ である. また，これらのデータを 後に示す式(1)のPower-lawモデル，およびGiesekus モデル10) (付録参照) によりフィットさせることで各々の物質定数を 算出した. 図中に示寸実線, 破線はそれぞれのフィット曲線 である.さらに， Table II-IにPower-lawモデルの物資定数 $m, n$ を示す. また, Table II-IIにGiesekusモデルの物質定数 $\eta_{\mathrm{p}}, \eta_{\mathrm{s}}, \lambda_{1}$, $\alpha$ を示す.ここで， $\lambda_{1}$ は弾性を表す無次元数Deの代表緩和時 
間， $\alpha$ は流動係数である. 実験において，供試流体の使用は 高せん断速度下における高分子鎖状構造の破壊による物性 の変化を避けるため各実験に対し 1 回のみの使用とした。ま た, 経時変化による影響を避けるためPAA水溶液は溶解後 24 時間以内で使用した。

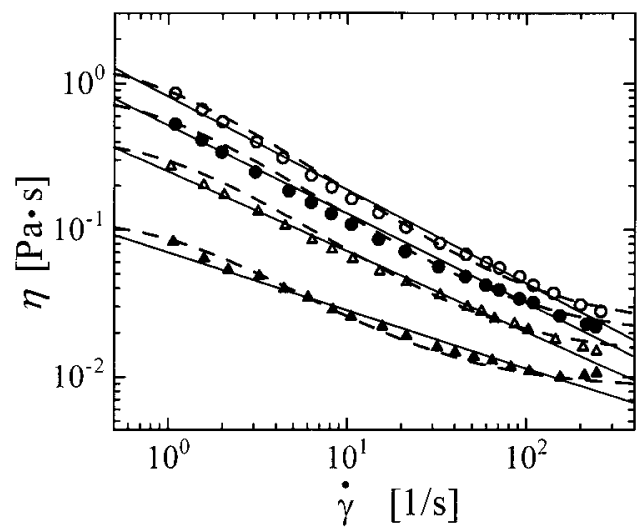

(1) Shear viscosity

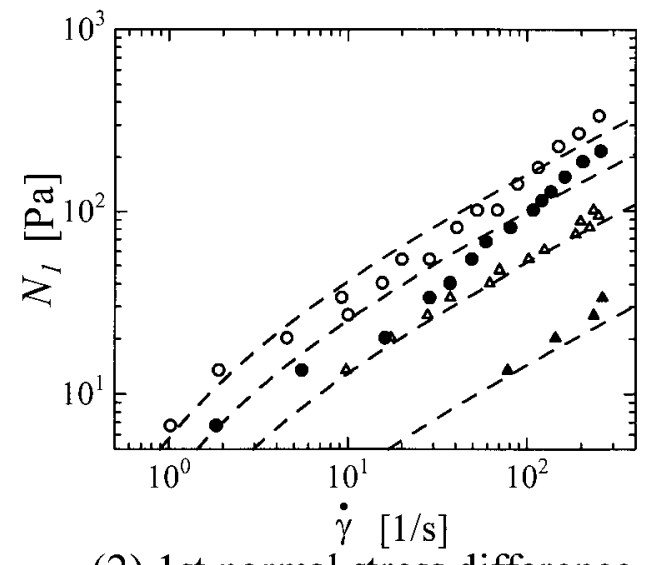

(2) 1st normal stress difference

- PAA500; $\triangle$ PAA1000;• PAA1500;0 PAA2000

Power-law model ; - - - Giesekus model ${ }^{10)}$

Fig.2 Rheological characteristics for PAA-water solutions.

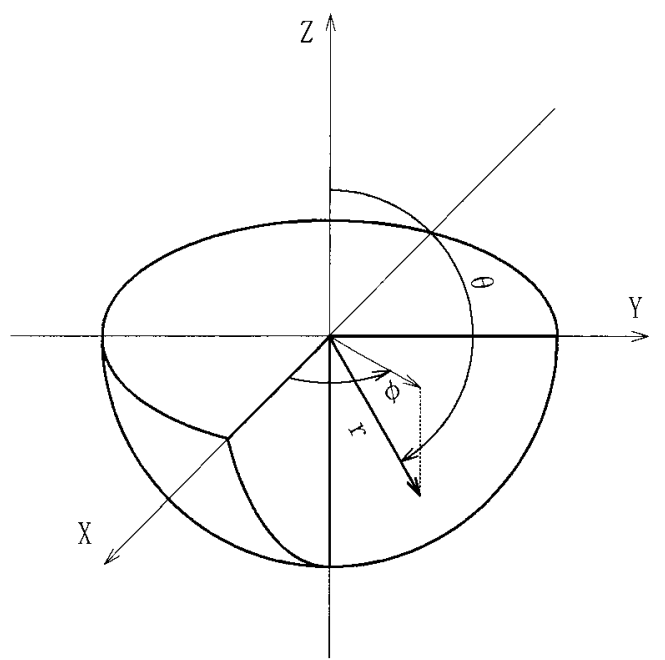

Fig.3 Spherical coordinate system.

\section{3. 結果および考察}

\section{1 理論的背景}

山口らによる前報のの研究，内半球回転外球殼静止時と同 様に, Power-lawモデル10)を適用し, 内半球静止外球殼回転時 における内半球へ加わる摩擦トルクの算出を行うこととす る.

外球款回転方向に対する主流の流れ方向を正とし，流体に 働く内半球 $r$ の方向面におけるトルク係数 $C m_{r}$ は,

$$
C m_{r}=2 \pi \frac{1}{R e^{*}}(1+\beta)^{2-n}\left\{\frac{3 / n \cdot \beta}{1-(1+\beta)^{-3 / n}}\right\}^{n} \int_{\pi / 2}^{\pi} \sin ^{2+n} \theta d \theta
$$

となる. また，内半球の赤道上 $\theta$ 方向面におけるトルク係数 $\mathrm{Cm} m_{\theta}$,

$$
C m_{\theta}=2 \pi \frac{1}{R e^{*}} \beta^{n}(1+\beta)^{2-n} \int_{0}^{1} \epsilon^{2}\left\{\frac{\epsilon}{\sqrt{(1+\beta)^{2}-\epsilon^{2}}}\right\}^{n} d \epsilon
$$

となる. 以上より, 内半球全面にかかるトルク係数 $C m$ は,

$$
\begin{aligned}
C m= & C m_{r}+C m_{\theta} \\
= & \frac{2 \pi}{R e^{*}}(1+\beta)^{2-n}\left[\left(\frac{3 / n \cdot \beta}{1-(1+\beta)^{-3 / n}}\right)^{n} \int_{\pi / 2}^{\pi} \sin ^{2+n} \theta d \theta\right. \\
& \left.+\beta^{n} \int_{0}^{1} \epsilon^{2}\left\{\frac{\epsilon}{\sqrt{(1+\beta)^{2}-\epsilon^{2}}}\right\}^{n} d \epsilon\right]
\end{aligned}
$$

となる.ここでRe*は一般化レイノルズ数であり, $R e^{*}=\rho$ $\left(r_{2} \omega\right)^{2-n}\left(r_{2}-r_{1}\right)^{n} / m$ で定義される. また, 無次元半径比 $\epsilon$ を $\epsilon=$ $r / r_{1}$ とした.

続いて，スラスト力について考える. 鉛直上向きを正とす ると内半球の $r$ 方向面を押し上げる力 $F_{r}$ は,

$$
F_{r}=2 \pi r_{1}^{2} \int_{\pi / 2}^{\pi}\left\{\left(\tau_{r r}-p\right) \cos \theta-\tau_{r \theta} \sin \theta\right\} \sin \theta d \theta
$$

と表せる. 同様に鉛直下向きを正とすると, 内半球の赤道上 $\theta$ 方向面を押し下げる力 $F_{\theta}$ は,

$$
F_{\theta}=2 \pi \int_{0}^{r_{1}}\left(\tau_{\theta \theta}+p\right) r d r
$$

と表せる．鈶直上向きを正とし，トルク係数と同様にスラス ト力も無次元化を行い，スラスト係数を以下のように定義す る.

$$
T m=\frac{F_{r}-F_{\theta}}{\rho r_{1}^{4} \omega^{2}}
$$

ここで, 本研究では Tmに対しては, 式(3)に示すような理論 的近似式を与えることができなかった。 すなわち，式(4) (5) に現れる応力および圧力に対応する速度場の見積もりが非 常に困難なためである.つまり式(3)のような忘力および圧力 と速度に対する単純な関数関係が成立しないためである. 
従って, 本研究では後に示す実験式により Tmに対する見積も りを与えるものとした．

\section{2 結果及び考察}

Fig.4に3 種類の間隙比を代表し $\beta=0.1538$ の場合について, グリセリン水溶液とPAA水溶液のトルク係数のレイノルズ数 に対する比較および式(3)による近似線を示す. 図中の (i) $\left(R e^{*}\right.$ $=10)$ および(ii) $\left(R e^{*}=300\right)$ は後に示す可視化結果のレイノル ズ数に対応する. Fig.4に示されるように, 式(3)は Shearthinning を考慮した近似式であり, 低レイノルズ数領域におい て, 式(3)と計測值は比較的よい一致を示すことがわかる。一 方, 高レイノルズ数領域では, 計測值と近似式に差異を生じ る. これは, 二次流れの発達により二球間隙での速度分布の 線形性が崩れるためであると考えられる.また, 全レイノル ズ数領域においてPAA水溶液の濃度による差が小さいことか ら, 弾性効果がトルク係数に及ぼす影響は微小であると考え られる。

同様にして, Fig.5に3種類の間隙比を代表し $\beta=0.1538$ の場 合についてグリセリン水溶液とPAA水溶液のレイノルズ数に

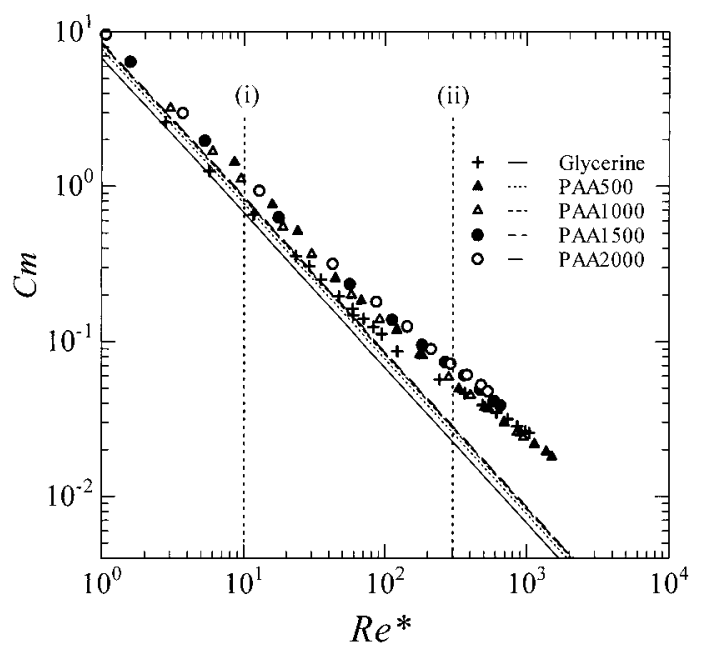

Fig.4 Generalized Reynolds number versus torque coefficient for glycerine and PAA-water solutions. $(\beta=0.1538)$

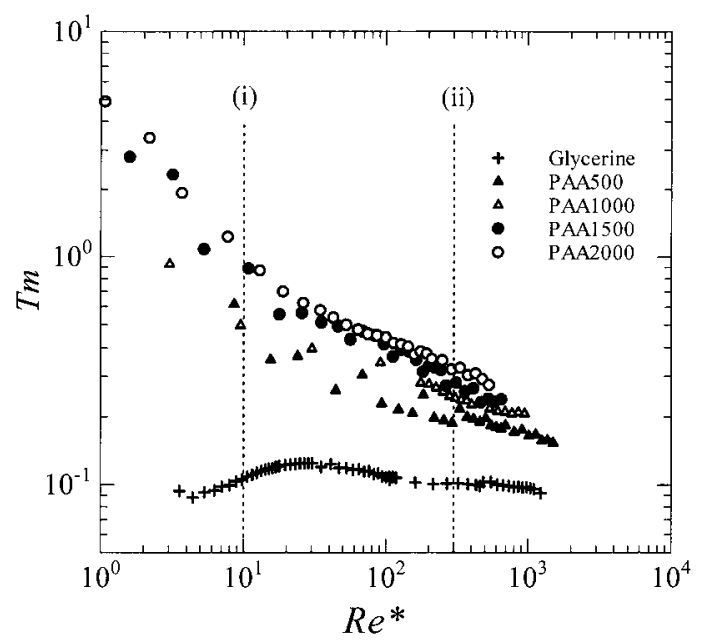

Fig.5 Generalized Reynolds number versus thrust coefficient for glycerine and PAA-water solutions. ( $\beta=0.1538)$
対するスラスト係数の比較を示す. Fig.5に示されるように, 全ての条件においてTmは正值となる. 寸なわち, 内半球は常 に上向きのスラストカを受けることが分かる．また，レイノ ルズ数が同じ条件ではグリセリン水溶液に対しPAA水溶液の Tmは非常に大きい值を示し, PAA濃度が濃いほどこの傾向は 強くなることが示された。これは，PAA水溶液がもつ法線応 力効果によるものと考えられる. 寸なわち, 南半球の間隙流 れでは流線方向にせん断応力の他に張力が発生し, それと垂 直な方向に圧力が生じるため, 内半球の南半球壁が鉛直上向 きに押し上げられるものと考えられる。 また，レイノルズ数 の増加に伴いスラスト係数は減少する。これは, 遠心力（慣 性力）の増大に対し，スラスト係数に対する弾性効果の影響 の割合が小さくなることを示す.

次に, トルク，スラスト特性に対応する流れ場の様子を表 すため, 代表例としてPAA2000, $\beta=0.1538$ の場合についての 可視化結果および模式図をそれぞれ各代表レイノルズ数 $R e^{*}$ $=10, R e^{*}=300$ に関してFig.6-(a) (b) (c)に示す．Fig.6-(a)は装置 正面からの可視化結果であり，主流方向の流れを示す. 図に 示されるように，主流方向の流れは常に層流であることが確 認された. 一方，PAA水溶液特有の現象として，Fig.6-(a)-(ii) に示されるように, $R e^{*}$ 増加に伴い南極付近より発生し, そ の後赤道方向に進行し, 二次流れの境界において消滅する帯 状構造を持つ渦の存在が確認された。 また，この渦は消滅し た後, 再び南極付近より発生し, 一連の変化を周期的に繰り 返すことが分かった．本研究では以下，この帯状構造をもつ 渦を“traveling cell” と呼称する. 北半球での球空間, 南半球で の球間隙における二次流れおよび traveling cellの様子を調べ るため，子午線断面上における可視化結果をFig.6-(b) (c) に示 す. Fig.6-(b)は南半球間隙断面の可視化結果であり, Fig.6-(b)-

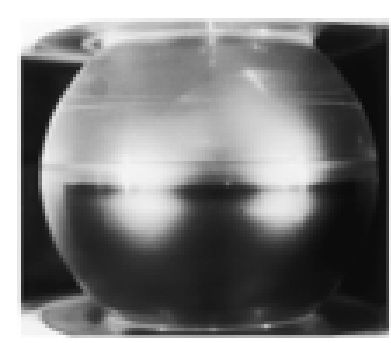

(i) $R=10$

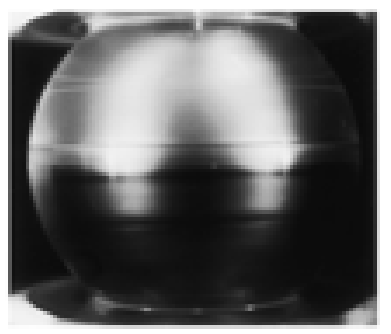

(ii) $E \cdot=300$

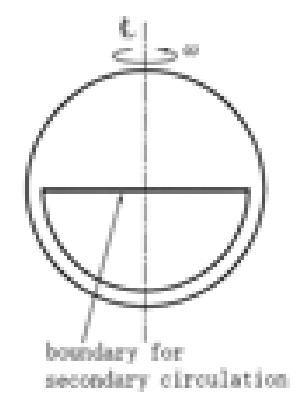

boundary for seceedary eirculation

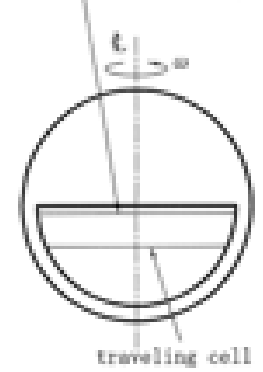

(a) Flor of the aainstrean direction

Fig.6 Visualization result for the PAA-water solutions. ( $\beta=0.1538$, PAA2000) 
(ii)に示されるように, traveling cell は外球殼壁面に沿って南極 から赤道へ移動することが確認され，断面に形成される二次 流れに沿う運動を伴うことが分かる. また, traveling cellの発 生に伴うトルクおよびスラスト特性への影響は少ないこと から, traveling cellは非常に微弱な循環であることが推測され る. また, Fig.6-(c)は北半球の二次流れの様子を示したもので ある. 北半球の二次流れはグリセリン水溶液と同様に外球殼
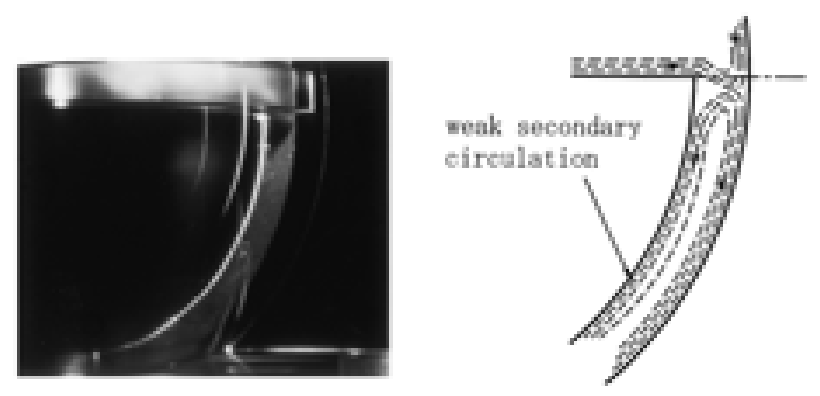

(4) $R A=10$
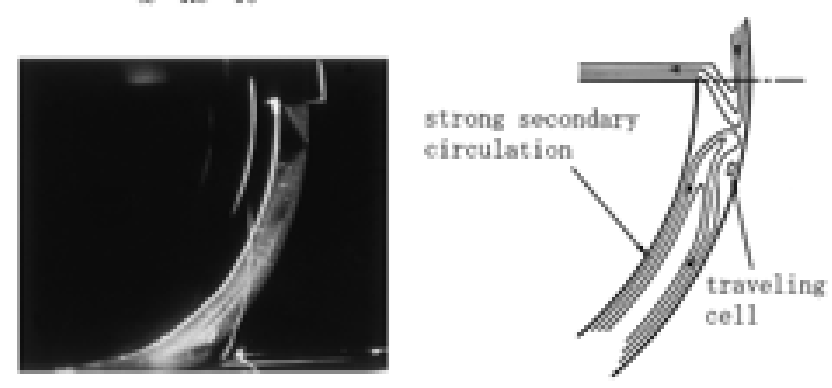

(ii) 8 Bా=900

(b) Secondary flow in gap space at Southern hemisphere

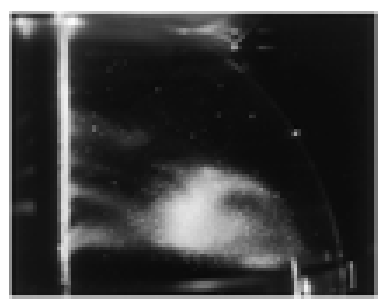

(1) $R E=10$

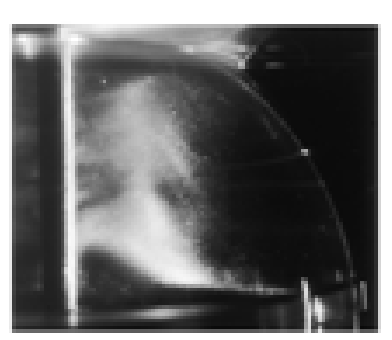

(i) $N O=300$
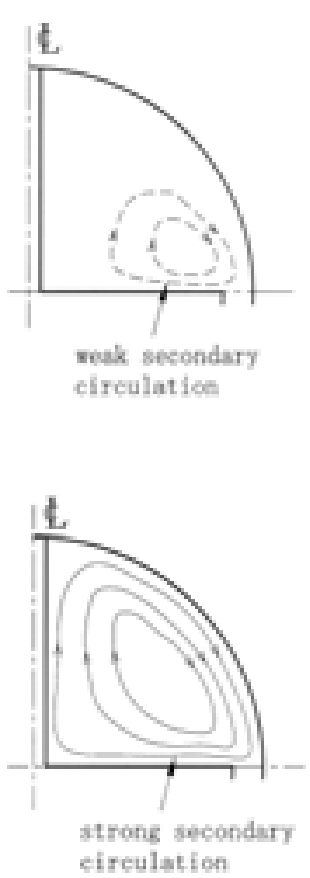

(c) Secondary flow at Northern hemisphere

Fig.6 (continued) Visualization result for the PAA-water solutions. ( $\beta=$ 0.1538 , PAAA2000)
に沿い北極から赤道へ向から方向に循環する. Fig.6-(c)-(i), (ii) の比較より, $R e^{*}$ の増加に伴い北半球の二次流れが発達する ことが確認された。 なお，本研究の実験範囲においてPAA水 溶液では内半球回転時 (外球殼静止時) に見られるT.G.渦, 流 れの遷移モード，あるいは乱流モードのは確認されなかった。

\section{3 実験式}

本研究における内半球壁面へのトルク，スラスト力の測定 結果より, トルク係数 $C m$ およびスラスト係数 $T m$ はレイノル ズ数, PAA 水溶液の弾性効果, 閒隙比が複雑に反映すること が明らかとなった。 そこで本研究では工学的応用を考慮し, トルク係数およびスラスト係数の結果を以下に示す実験式 で整理することを試みた. Cmおよび $T m$ の濃度による変化を 考慮するためPAA水溶液の弾性効果を表す無次元数としてデ ボラ数を採用し, 以下のように定義した.

$$
D e=\lambda_{1} \frac{r_{2} \omega}{r_{2}-r_{1}}
$$

トルク係数およびスラスト係数の式の形を慣性項, 粘性項, 弾性項および間隙比の項に分割し以下のように仮定した.

$$
\begin{aligned}
& C m^{*}=C_{1}\left(1+C_{2} \frac{1}{R e^{*}}+C_{3} \frac{D e}{R e^{*}}\left(1+\frac{\zeta}{R e^{*}}\right)\right)^{k_{1}}\left(1+C_{4} \beta\right)^{k_{2}} \\
& T m^{*}=C_{5}\left(1+C_{6} \frac{1}{R e^{*}}+C_{7} \frac{D e}{R e^{*}}\left(1+\frac{\zeta}{R e^{*}}\right)\right)^{k_{3}}\left(1+C_{8} \beta\right)^{k_{4}}
\end{aligned}
$$

ここで, $C m^{*}$ は実験式によるトルク係数, $T m^{*}$ は実験式による スラスト係数であり, $C_{1} \sim C_{8}, k_{1} \sim k_{4}$, $\zeta$ は実験定数である. 本研究では，これら実験定数については，可能な組み合わせ について演算を行い，実験定数を最もよく整理できるものを 求めた. 以上, $C m^{*}, T m^{*}$ と $C m, T m$ の相関を行い, 式を整理 した結果次の実験式を得た。

$$
\begin{aligned}
& C m^{*}=0.0057\left(1+2000 \frac{1}{R e^{*}}\right)^{0.90}(1+\beta)^{3.3} \\
& T m^{*}=0.11\left(1+1.5 \frac{D e}{R e^{*}}\left(1+\frac{6.5}{R e^{*}}\right)\right)^{0.84}(1+2.7 \beta)^{0.42}
\end{aligned}
$$

ここで, 式(10)については相関の結果, 式(8)の実験定数 $C_{3} \approx 0$ となるため弾性項を消去した。 また, 同様に式(11)について は相関の結果, 式(9)の実験定数 $C_{6} \approx 0$ となるため粘性項を消去 した. 式(10)より得られるトルク係数 $\mathrm{Cm}^{*}$ と実験で得られたト ルク係数 $C m$ の相関図をFig.7 に示す．図に示されるように実 験式(10) は実験值と良い一致を示す。このことからも，PAA 水溶液の弾性効果がトルクに与える影響は微小であること が分かる. 一方, 式(11)より得られるスラスト係数 $T m^{*}$ と実験 で得られたスラスト係数 $T m$ の相関図をFig.8に示す. 図に示さ れるように実験式(11) は実験值と良い一致を示す。このこと からも，スラスト力にPAA水溶液の弾性効果が大きく影響を 及ぼすことが分かる。

最後に, 本研究の結果より外球款回転内半球静止の条件で は, 内半球回転外球凯静止時に見られる流れのモード変化に よるT.G.渦の発生およびこれに伴うトルク，スラスト特性の 
変化は認められない。この点において, 複雑なモード変化の 少ない外球殼回転内半球静止の条件は弾性効果によるスラ ス卜特性を良く表し, 粘性効果によるトルク特性を良く表す ため, レオロジー計測機能が期待される. さらに, 弾性効果 を評価するレオメータとしての半球回転粘度計一の応用が 考えられる.

\section{4. 結言}

本研究の外球殼回転-内半球静止時における粘弾性流体の 半球間隙流れに関して次のような結論を得た。

1. 前報 ${ }^{3)}$ の内半球回転時と同様にして, 本研究における 外球殼回転時においても，二次流れの影響を無視できる
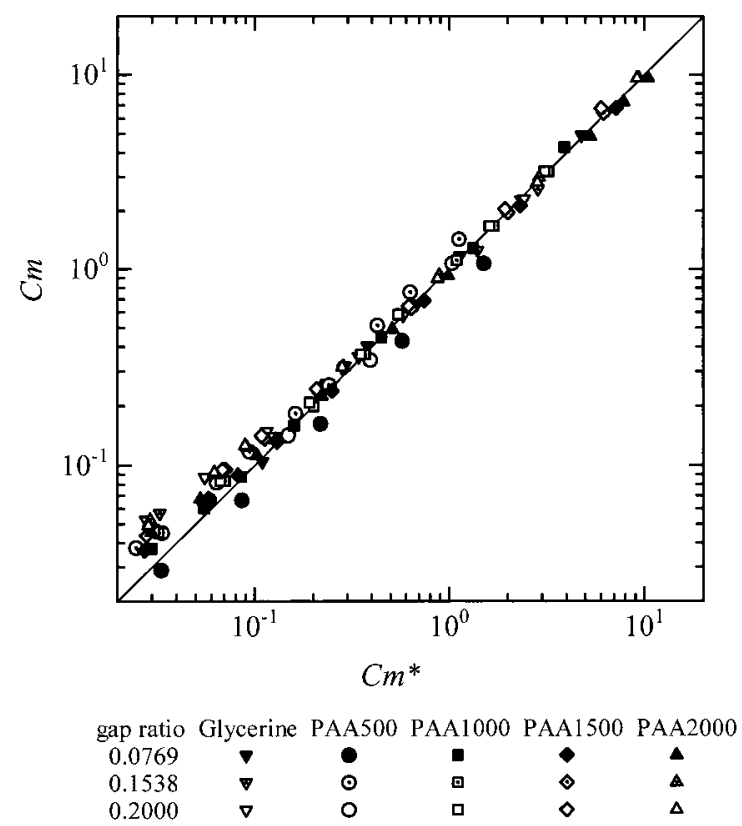

Fig.7 Correlation diagram for torque coefficient.

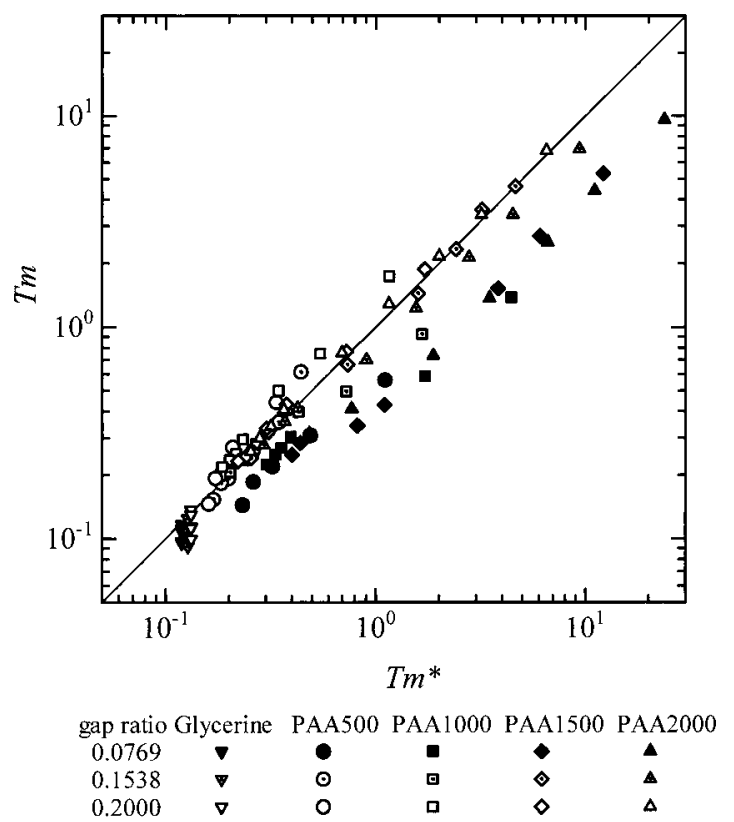

Fig. 8
低レイノルズ数の範囲において，トルク係数はPower-law モデルを用いた近似式によりよく表現できる．また，ス ラスト係数は粘弾性流体の弾性効果の影響を強く受け ることがわかった。

2. 外球殼回転時では内半球回転時と比べて, 発現する流 れモードは非常に単純であり，唯一確認されたモード変 化は, レイノルズ数の増加に伴い, 南極付近から帯状構 造をもつ渦(traveling cell)が発生するものである.

3. 前報3で確認された upper vortex, T.G.渦, スパイラル T.G. 渦, 本研究で確認された traveling cellはトルクおよび スラスト特性への影響が少ないことがわかった。

4. トルク係数のデータは一般化レイノルズ数と間隙比 を用いた実験式(10)により良く整理できる．また，スラ スト係数のデータはデボラ数を加えた実験式(11)により 良く整理できる。

\section{謝辞}

本研究の一部は，株式会社ソフトウェアクレイドルの支援 を受けた。記して敬意を表すままた，文部科学省高度推進化 経費「新技術開発研究プロジェクト」の支援を受けた。記し て敬意を表す。

\section{参考文献}

1) 中林功一, 日本機械学会論文集 B, 49-443, 1329 (1983).

2) 中林功一, 日本機械学会論文集 B, 50-449, 11 (1984).

3) 中林功一, 日本機械学会論文集, 42-363, 3451 (1976).

4) Yamaguchi H, Fujiyoshi J, Matsui H, J Non-Newtonian Fluid Mech, 69, 29 (1997).

5) Yamaguchi H, Matsui H, J Non-Newtonian Fluid Mech, 69, 47 (1997).

6) 山口博司, 森下昌俊, 日本レオロジー学会誌，28, 105 (2000).

7) Egbers C, Rath HJ, Acta Mechanica, 111, 125 (1995).

8) Wimmer M, J Fluid Mech, 78, 317 (1976).

9) Rofe CJ, Lambert RK, Callaghan PT, J Rheol, 38, 875 (1994).

10) 中村喜代治，“非ニュートン流体力学”, (1997), コロナ 社, 東京, $\mathrm{p} 45,69$, 141-145.

\section{付 録}

Material Function for the Giesekus model.

Steady shear flow :

$$
\begin{gathered}
\eta(\dot{\gamma})=\eta_{s}+\eta_{p} \frac{(1-f)^{2}}{1+(1-2 \alpha) f} \\
\frac{\Psi_{1}(\dot{\gamma})}{2 \lambda_{1}\left(\eta_{0}-\eta_{s}\right)}=\frac{f(1-\alpha f)}{\left(\lambda_{1} \dot{\gamma}\right)^{2} \alpha(1-f)}
\end{gathered}
$$

where,

$$
\begin{aligned}
f & =\frac{1-\chi}{1+(1-2 \alpha) \chi} \\
\chi^{2} & =\frac{\left(1+16 \alpha(1-\alpha)\left(\lambda_{1} \dot{\gamma}\right)^{2}\right)^{1 / 2}-1}{8 \alpha(1-\alpha)\left(\lambda_{1} \dot{\gamma}\right)^{2}}
\end{aligned}
$$

